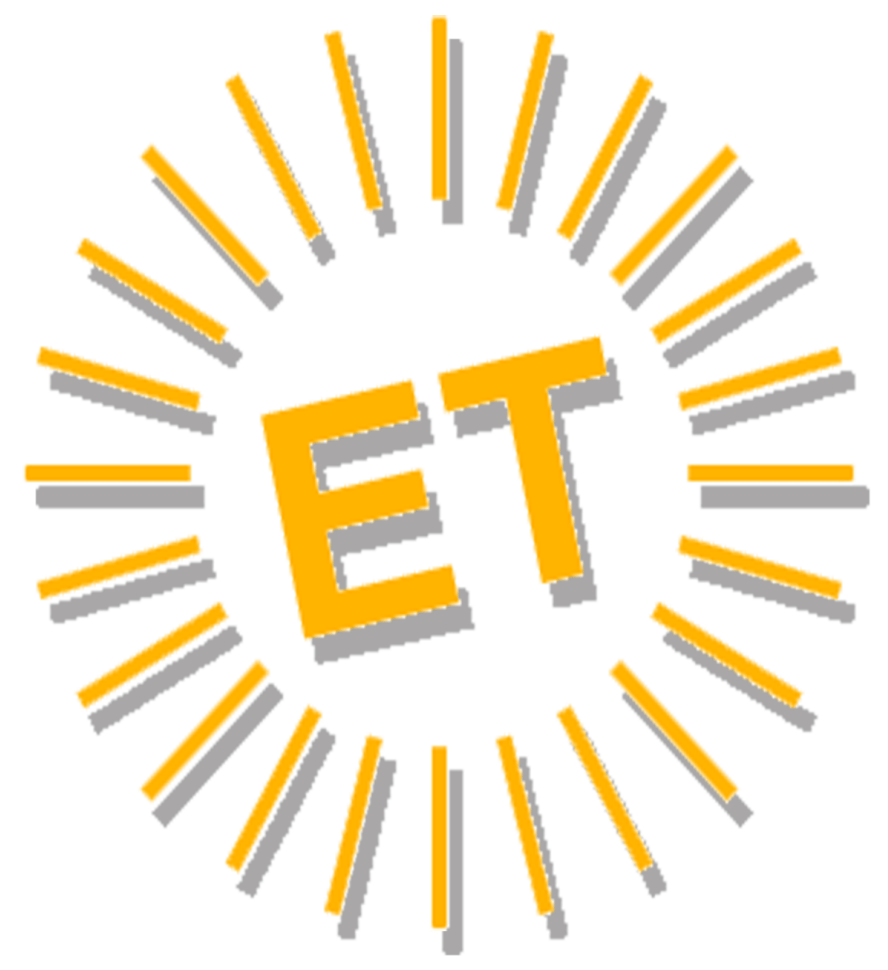




\section{Editorial Team}

\section{Editor in Chief}

Alfonso Vargas-Sánchez, University of Huelva, Spain

\section{Associate Editor}

Mirko Perano, Reald University College, Albania

\section{Books Review Editor}

Brendan Paddison, York St. John University, United Kingdom

\section{Secretariat}

Elena García de Soto, University of Huelva, Spain

Cinta Borrero-Domínguez, University of Seville, Spain

\section{Style reviewer and text editor}

Anestis Fotiadis, Zayed University, United Arab Emirates

\section{Editorial Board}

José Manuel Alcaraz, Murdoch University, Australia Mario Castellanos-Verdugo, University of Seville, Spain José Antonio Fraiz-Brea, University of Vigo, Spain José Manuel Hernández-Mogollón, University of Extremadura, Spain

Tzung-Chen Huan, National Chiayi University, Taiwan, Province of China

Shaul Krakover, Ben Gurion University, Israel Jean Pierre Levy-Mangin, University of Quebec, Canada Tomás López-Guzmán, University of Córdoba, Spain Yasuo Ohe, Chiba University, Japón

María de los Ángeles Plaza-Mejía, University of Huelva, Spain Nuria Porras-Bueno, University of Huelva, Spain João Albino Silva, Algarve University, Portugal

\section{Advisory Board (Spanish Members)}

Juan Manuel Berbel-Pineda, Pablo de Olavide University, Spain César Camisón-Zornoza, Uniersity of Valencia, Spain Enrique Claver-Cortés, University of Alicante, Spain María Teresa Fernández-Alles, University of Cádiz, Spain José Luis Galán-González, University of Seville, Spain Félix Grande-Torraleja, University of Jaén, Spain

Antonio Leal-Millán, University of Seville, Spain Inmaculada Martín-Rojo, University of Málaga, Spain Antonio Manuel Martínez-López, University of Huelva, Spain Francisco José Martínez-López, University of Huelva, Spain Pablo A. Muñoz-Gallego, University of Salamanca, Spain
Francisco Riquel-Ligero, University of Huelva, Spain José Miguel Rodríguez-Antón, Autonomous University of Madrid, Spain

Sandra Sanchez-Cañizares, University of Cordoba, Spain Josep Francesc Valls-Giménez, ESADE, Spain

\section{Advisory Board (Other European Members)}

Tindara Abbate, University of Messina, Italy Paulo Aguas, University of Algarve, Portugal Carlos Costa, Aveiro University, Portugal Dianne Dredge, Aalborg University, Denmark Salvatore Esposito de Falco, University of Rome "La Sapienza", Italy

Sheila Flanagan, Dublín Institute of Technology, Ireland Tania Gorcheva, Tsenov Academy of Economics, Bulgaria Tadeja Jere Jakulin, University of Primorska, Slovenia Metin Kozak, Mugla University, Turkey Álvaro Matias, Lusiada University, Portugal Alfonso Morvillo, National Research Council, Italy Alexandru Nedelea, Stefan cel Mare University of Suceava, Romania Claudio Nigro, University of Foggia, Italy Angelo Presenza, University "G. D'Annunzio" of Chieti-Pescara, Italy

Kanes Rajah, Royal Agricultural University, United Kingdom

\section{Advisory Board (Members from the rest of the world)}

John Allee, American University of Sharjah, United Arab Emirates

Nestor Pedro Braidot, National University of La Plata, Argentina

Roberto Elias Canese, Columbia University, Rector, Paraguay

Luca Casali, Queensland University of Technology, Australia Nimit Chowdhary, Indian Institute of Tourism and Travel Management, India

Steven Chung-chi Wu, National Pingtung University of Science and Technology, Taiwán

Dianne Dredge, Southern Cross University, Australia Daniel Fesenmaier, Temple University, United States

Babu George, Alaska Pacific University, United States Dogan Gursoy, Washington State University, United States Jafar Jafari, University of Wisconsin-Stout, United States Sanggun Lee, Pai Chai University, Korea Republic of Albert Yeh Shangpao, I-SHOU University, Taiwán Pauline Sheldon, University of Hawaii, United States Germán A. Sierra-Anaya, University of Cartagena de Indias, Rector, Colombia Xiaohua Yang, University of San Francisco, United States 


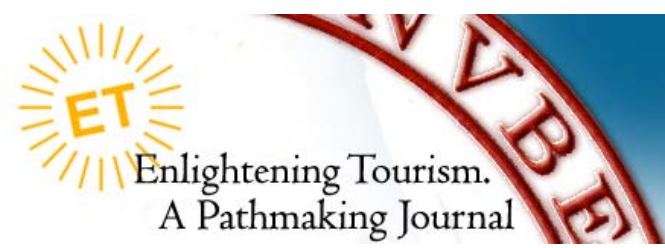

Huelva

A Pathmaking Journal

\title{
A FUZZY-ANALYTIC HIERARCHY PROCESS \\ OF TOURISM SUPPLY CHAIN \\ PERFORMANCE: CUSTOMER PERSPECTIVES
}

\author{
Rio Benedicto Bire \\ State Polytechnic of Kupang (Indonesia) \\ rio.bire@gmail.com \\ Yudha Eka Nugraha \\ State Polytechnic of Kupang (Indonesia) \\ yudhaekanugraha@gmail.com \\ Fahri Reva Adiputra Welly \\ State Polytechnic of Kupang (Indonesia) \\ fahrireva11@gmail.com
}

\begin{abstract}
Evaluation of end-to-end tourism supply chain performance from the end customer (tourist) perspective is missing from literature, which necessitates for investigation. As the end customers are involved throughout all stages of the tourism supply chain, and that the tourism product is merely that of tourist experience and satisfaction, the agenda is considered quintessential. Accordingly, this research aims to investigate tourism supply chain management (TSCM) performance attributes from the tourists' point of view. This study takes its setting in the Nusa Tenggara Timur (NTT) Province of Indonesia, a flourishing prospectus of tourism sector in the country. A Fuzzy - Analytical Hierarchy Process (F-AHP) method was employed to examine the relative importance of the criteria and sub-criteria of TSCM. Results render the stages prior to travelling as the most essential phases in the tourism supply chain that influences satisfaction in the travelling experience. Moreover, the three most critical performance criteria are visa and/or other pre-travel document arrangements cycle time, accuracy of information about the destination, and accuracy of information in the booking process. Aside from practical
\end{abstract}


insights, our findings also present a foundation for further investigation into other dimensions of TSCM performance.

\section{KEYWORDS}

Fuzzy AHP; Indonesia; MCDM; Tourism Supply Chain Performance.

ECONLIT KEYS

Z3; Z30; Z39

\section{INTRODUCTION}

Tourism as one of the world's most rapid growing industries (Nilashi, Yadegaridehkordi \& Ibrahim, 2019), is a critical enabler for the development of growing economies (Cucculelli \& Gof, 2015). Figures regarding international arrivals and receipts have continued to outpace that of the world economy (World Tourism Organization, 2020), where tourist visits managed to reach 1.46 billion in 2019 . Accordingly, many developing countries have emphasized strategic lenses towards tourism development. Albeit, the tourism product is considered complex (Palang \& Tippayawong, 2019), which alludes to the necessity for innovative managerial efforts in order to build competitive advantage.

The supply chain management (SCM) as a renowned framework for creating and sustaining competitive advantage in various industries, is considered to serve the tourism industry in similar manner (Ghaderi et al., 2018; Palang \& Tippayawong, 2019). Accordingly, the tourism supply chain management (TSCM) perspective has been uprising in the academic world, although relatively limited (Szpilko, 2017). TSCM is defined as a set of approaches that serves for the efficient management of chain operators to satisfy the needs of tourists (Zhang et al., 2009). An emphasis of this definition lies in the participation of a series of actors instead of a single firm. Accordingly, integration among the different components of the chain which commonly comprise of second tier suppliers (i.e. local producers), first tier suppliers (i.e. accommodation, transportation), tour operators and/or travel agents as the focal company, tourists as end customers (Soratana et al., 2021) are critical towards the success of the value delivery (Guo, Ling, Dong \& Liang, 2013). The unique structure of TSCM that encompasses a wide range of different sectors such as accommodation, transportation, food and beverages, and creative economy among others, entails specific managerial constructs such as that of performance measurement which 
provide important insights towards better supply chain practices. Palang \& Tippayawong (2019) remark that performance measurement provides evaluation on the efficiency and effectiveness of the supply chain. Moreover, continuous improvement is stipulated in the tourism system (Ghaderi et al., 2018), one which can be facilitated by comprehensive performance measurement frameworks. Albeit, studies into investigating the performances of TSCM remains scarce (Yilmaz \& Bititci, 2006; Huang, 2018).

Available literature on TSCM performances generally focuses on that of single firms and not encompassing the whole chain (Sigala, 2008), where the limited studies tend to be centred on hotels, travel agencies, and destination efficiency (Huang, 2018). Furthermore, within such scarcity, researches tend to bypass the perspective of the supply chain end customers i.e., tourists. Sutono (2019) remarks that a customer oriented supply chain can boost for better tourism performances, which is also supported by Mete \& Acuner (2014) who state that the tourist perspective is essential for enhancing competitiveness of tourism value chains. Similar to the general TSCM performance literature however, studies focusing on the tourist perspective tend to be concentrated on the individual service sectors only (Song, 2012), predominantly hotels and travel agencies. Nonetheless, recent studies such as Huang (2018) assessed performances of a comprehensive supply chain instead of a single actor, yet did not include the final component of the chain. A similar argument can be made for the study of Palang \& Tippayawong (2019) which overlooked the tourists' standpoint. Ghaderi et al. (2018) presented an analysis of supply chain performances from the tourist perspective, yet failed to exhibit the holistic value delivery process encompassing the pre-delivery and post-delivery stages. Accordingly, there is a gap into investigating the all-inclusive TSCM performance framework from the tourist point of reference, which is attempted to be met by this study. The Fuzzy - Analytic Hierarchy Process (F-AHP) is a renowned, prevalent technique for dealing with fuzziness and uncertainty of multicriteria decision-making (Kubler et al., 2016) such as that of tourist attitude, which serves this study by revealing weights of performance criteria along the tourism supply chain. Results are contended to provide a better understanding of TSCM performance from the perspective of tourists. 
This study takes its setting in the Nusa Tenggara Timur (NTT) Province of Indonesia. The region which is home to the ancient Komodo dragon has recently recorded a fourfold growth of tourist visits from roughly 300 thousand to 1.2 million people in the last past 5 years (BPS Nusa Tenggara Timur, 2019). Additionally, NTT was voted as the World's number 1 destination to visit in 2020 according to Lonely Planet (2019), implying to the compelling tourism potential to be developed. In a wider scale, tourism is realized as the leading sector of Indonesia's strategic development plan (Kementrian Pariwisata Indonesia, 2019). However, in terms of tourism contribution towards national revenue, the nation is relatively lagging behind other countries with similar substantial revenues from tourism, thus pointing to weak supply chain performance (Sutono, 2019). Amidst the prevalent circumstances however, the devastating impacts of the novel coronavirus (COVID-19) outbreak which has been declared as a public health emergency of international concern by the World Health Organization (WHO) in 2020, has created a whole new level of challenge for the tourism industry. Consequently, tourism supply chains are subject to major adaptations particularly considering tourist attitudes in the different stages of the value delivery, which render an imperative gap for empirical studies to explore.

Drawing from what has been laid out above, the objective of this study is to investigate TSCM performance criteria from the tourists' point of view by application of the certain F-AHP method. Linking to the dynamic environment as a consequence of the COVID-19 pandemic, this research justifies its contribution. This study can be categorized as a case study perspective, which will lead to a better understanding of the TSCM potential in NTT province, a region whose potential for the development of tourism has not been sufficiently explored yet.

The introduction above has provided a preface to this study. Accordingly, the remainder of this article is structured as follows: a literature review comprising relevant literatures in accordance to the research topic, a research methods section laying out the approaches and methods used to fulfil the research aim, a results and discussion section, and a conclusion which recognizes the study limitations and directions for future works. 


\section{LITERATURE REVIEW}

The tourism industry necessitates an integrated perspective towards endeavours of its analysis and management (Soratana et al., 2021), one that can serve as a source for gaining competitive advantage through the concept of supply chain management (SCM) (Song, 2012). Tourism supply chain management (TSCM) is a growing topic in literature (Szpilko, 2017; Huang, 2018), which is defined by Zhang et al. (2009) as a set of principles to an efficient planning, organizing, leading, and controlling of operations of the different actors involved in meeting the needs of visitors in a specific tourist destination. These distinct actors typically include accommodation and transportation companies, tour operators and/or travel agents, and tourists as the end member of the chain.

As the tourism product is recognized to be more complex than that of commercial ones (Yilmaz \& Bititci, 2006; Soratana et al., 2021), it entails distinctive features that sets the groundwork for any efforts in managing the supply chain. Intangibility is regarded as a unique characteristic to the tourism product, rendering easiness in distribution yet difficulty in purchasing. Moreover, inseparability, perishability, heterogeneity, and ownership also constitute for the differing attributes (Evans, et al., 2002). Zhang et al. (2009) also includes higher demand fluctuation and more intricate dynamics to add to the typical features within the tourism supply chain.

Albeit, for the tourism supply chain to reach its maximum potential and increase competitiveness, effective performance measurement is of critical importance (Song, 2012; Palang \& Tippayawong, 2019). Regardless, studies concerning TSCM performance is relatively limited. Among the related literature, performances are generally centred only on the focal company or organizations that generally "dictate" the flow of products (Sigala, 2008; Bai \& Chen, 2021). Moreover, researches that do take into perspective all members of the supply chain tend to disregard the end customer i.e., tourist viewpoint. Nevertheless, the tourist point of reference is considered imperative towards TSCM competitiveness (Mete \& Acuner, 2014; Sutono, 2019). Recent empirical investigation includes Huang (2018), who applied a hybrid network data envelopment analysis that covers education, hotel, travel agents, and destination as divisions of the supply chain, yet did not consider tourists frame of 
reference. Similarly, Palang \& Tippayawong (2019) presented a framework of TSCM performance measurement that included samples from different business components of the supply chain ranging from transportation, accommodation, excursion, and tour operators, but missed the tourist perspective. Moreover, Song (2012) recognizes studies that lean towards the tourist orientation tend to be concentrated on individual sectors only.

Several researches however, have seen to take a more comprehensive stance concerning the tourist standpoint. A recent empirical study worth mentioning is that of Ghaderi et al. (2018) that assessed tourists' satisfaction by referring to multiple services in the tourism value delivery. The study however, merely focused on tourist experiences at the destination thus overlooked the pre-travel and post-travel stages of the supply chain. Moreover, Xu \& Gursoy (2015) assessed tourists' attitude and behaviour from a sustainable hospitality SCM reference that focuses on the chain of hotels and hotels' suppliers. Despite recognizing multiple actors in the supply chain, the study did not refer to other chain members such as transportation and tour operators. On another note, Sigala (2014) presented a framework related to tourists' involvement in sustainable TSCM that encompasses more inclusive stages in the supply chain, ranging from design, procurement, production, distribution, marketing, a consumption, and reverse logistics. The study however, did not get in detail concerning performance criteria.

Pertaining to performance measurement frameworks in TSCM, evaluation metrics are presented in very limited studies. In the general service supply chain, Cho et al. (2012) put forward order process management, supplier relationship management, service performance management, capacity and resources management, customer relationship management, demand management, information and technology management, and supply chain finance management as the set for evaluating supply chain efficacy. In the context of TSCM, Zhao \& Hou (2021) presented the adoption of theory of constraints (TOC) performance measures and the drum-buffer-rope model for tourism management. The framework, however, is considered more suitable to facilitate the supply chain dynamics from the company's perspective. Taking into account a more comprehensive perspective, Yilmaz and Bititci (2006) developed a framework by deriving from the renowned supply chain operation reference (SCOR) 
for assessing tourism supply chains as an end-to-end seamless product. The model comprises criteria from both company and tourist standpoints in all stages along the supply chain, the latter provisioning an extension to the spectrum of tourism value chain. Such in particular is supported by Song (2012) who asserts that from a customer perspective, the tourism product is viewed as a value-added chain comprising of different service components. Some studies (Heikkilä, 2002; Vollmann \& Cordon, 1998) even suggested using the term demand chain management over supply chain management (SCM), thus emphasizes significance of the tourist frame of reference in TSCM.

The tourism supply chain performance framework developed in Yilmaz \& Bititci (2006) is set into 3 levels, which comprise of the scope and content of operations (level 1), performance measurement criteria through four primary stages of the tourism supply chain, defined as win order/booking, pre-delivery (pre-travel), delivery, and post-delivery (post travel) stages (level 2), and a breakdown of the delivery stage and making up a level 3 if necessary. Each level present both company and customerfacing performance metrics. As the customer-facing metrics in level 1 primarily reflect the SERVQUAL attributes of Parasuraman et al. (1998), we argue that the four stages at level 2 can be set as the cornerstone to measuring TSCM performances from the tourist perspective by setting each metric within to mirror the SERVQUAL dimensions (reliability, responsiveness, assurance, tangibles, empathy, and value of money) defined in level 1. Nevertheless, the customer-facing metrics along the four stages of the supply chain include purchasing cycle time, number of complaints on contact person, and number of misinformation given (win order stage), visa handling cycle time and number of customer complaints on information (pre-deliver stage), service quality of accommodation, transportation, and incoming travel agents (delivery stage), and customer satisfaction survey and feedback (post-delivery stage). To the best of our knowledge, this particular framework is the only one of its kind in regards to exhaustive TSCM performance concerning the tourist standpoint, which has yet to be further tested in empirical studies.

To add to the matter, today's tourism supply chains are overwhelmingly distressed by the outbreak and ongoing pandemic of the COVID-19 (Torres et al., 2020). As the tourism industry is very sensitive and vulnerable to any risk situation caused by 537 
external factors including epidemic outbreaks (Jiang \& Ritchie, 2017), consequently the tourism value delivery is presented with a whole new era to deal with. Such also extends into the realm of TSCM performances which heavily relies on the tourist as the main trigger of the chain's activities. One of the major effects of COVID-19 is the shift in tourist attitudes (Nazneen, 2021). Accordingly, the whole experience of supply chain delivery in the COVID-19 era is bound to certain adjustments influencing the performance in general, creating an interesting area to be dealt with.

In order to draw a better understanding of TSCM performance, application of a multi-criteria decision making (MCDM) is considered robust to solve the multiple construct case. Fuzzy - Analytical Hierarchy Process (F-AHP) is a powerful MCDM technique used predominantly in empirical studies in the field of manufacturing, industry, and government categories (Kubler et al., 2016), which has also seen several applications in the tourism context (For example, see Wang et al. (2014) Fu et al. (2011), Makui \& Nikkhah (2011), and Lin et al. (2009)). The application of F-AHP in these studies present robust results, however the evaluations are based upon one particular component of the tourism supply chain only, i.e., cruise company, travel intermediary, hotel, which presents a gap for an analysis to encompass more than one certain chain member. A particular strength of F-AHP includes the ability to overcome vagueness of human judgements, one where it is difficult to assign crisp values towards the decision (Chan \& Kumar, 2007). Hence, based on the fuzzy AHP method, it could help decision markers deal with multiple criteria decision-making problems under the fuzzy environment (Ip et al., 2012). Moreover, Fu et al. (2011) asserts that as the traditional AHP may not be able to truly capture the complexity of people's decisions, the incorporation of fuzzy numbers into AHP provides the means to solve uncertain fuzzy problems and rank excluded factors based on weight ratios.

Drawing from previous works aforementioned, the TSCM literature presents specific areas that can be further explored. In the first place, studies typically are centred on the focal company and their immediate chain members only (Sigala, 2008; Bai \& Chen, 2021). When three or more members are considered, the tourist point of view is generally bypassed (i.e., Huang, 2018; Palang \& Tippayawong, 2019). Respectively, when the tourist attitude is assessed, researches tend to come short in recognizing the all-inclusive stages along the supply chain (i.e., Ghedari et al., 2018; 
$\mathrm{Xu} \&$ Gursoy, 2015). The gap is further amplified in the context of performance measurement, where among limited customer-facing criteria available (i.e., Yilmaz \& Bititci, 2006; Cho et al., 2012; Zhao \& Hou, 2021), there is almost an inexistence of empirical studies into testing the available framework that encapsulates the whole tourism product value delivery. Considering the state of TSCM in midst of the COVID19 pandemic, the extent further renders an insightful scope. Accordingly, this study contributes to literature in providing a better understanding on TSCM performances based on the tourist frame of reference through the certain F-AHP approach in midst of a challenging era in the tourism industry.

\section{RESEARCH METHODOLOGY}

\section{1) DATA COLLECTION METHOD}

In order to obtain data from end-customers of the tourism supply chain, a sample of visiting tourists to the NTT Province from a time period of 9 months (January to September 2020) were targeted and approached through local travel intermediaries. A total of 24 tour operators and travel agencies assisted by spreading survey questionnaires towards their customers through the email platform. All customers of the travel intermediaries above the age of 17 that were available to be approached via email were sampled to fill in the questionnaire. Respectively, a total of 450 questionnaires were distributed towards incoming national and international tourists.

\section{2) MEASUREMENT TECHNIQUE: F-AHP}

Measuring real-life problems is oftentimes inadequate through applications of crisp numerical values (Mehrjerdi, 2012) since human judgements tend to be ambiguous. The fuzzy set theory was introduced by Zadech (1965) in order to overcome issues related to the vagueness of human's decisions that provides partial set memberships instead of crisp ones. Tseng \& Yip (2021) argues that exact numerical values in the classical AHP may not fully represent judgements, where in essence, it is certain that an element either belongs to a set or not. However, in fuzzy logic, an element might be partially inside the set or partially outside the set. Incorporating the fuzzy set into AHP aids for overcoming uncertainties in the pairwise comparisons of traditional AHP. Accordingly, the fuzzy series used in this research adopts that of Ip et al. (2012) which comprise a triangular number set defined as $(\mathrm{l}, \mathrm{m}, \mathrm{u})$. 
The procedure for F-AHP in order to rank criteria of the tourist-facing TSCM performance follows the concepts from Chang (1996), with an addition of a defuzzification step in the final procedure in order to simplify interpretation of results as:

1. Obtaining Normal Pair-Wise Comparison Matrix (PCM) and Fuzzifying the Normal PCM to Fuzzy PCM.

In this step, the triangular fuzzy number set $(I, m, u)$ is obtained from the fuzzification of the crisp PCM value to the fuzzy PCM value as displayed in Table 1 as adopted from Wang et al. (2020). A fundamental crisp scale from 1 to 9 is used, with 1 representing two criteria of equal importance and 9 indicating the perfect order of difference between two criteria under assessment.

\begin{tabular}{c|l|c}
\hline Crisp PCM Value & Linguistic Variable & Fuzzy PCM Value \\
\hline 9 & Perfect & $(9,9,9)$ \\
\hline 8 & Absolute & $(7,8,9)$ \\
\hline 7 & Very Important & $(6,7,8)$ \\
\hline 6 & Fairly Important & $(5,6,7)$ \\
\hline 5 & Important & $(4,5,6)$ \\
\hline 4 & Preferable & $(3,4,5)$ \\
\hline 3 & Not Bad & $(2,3,4)$ \\
\hline 2 & Weak Importance & $(1,2,3)$ \\
\hline 1 & Equal Importance & $(1,1,1)$
\end{tabular}

Table 1: Pairwise Comparison Scales for F-AHP.

The normal PCM, A, is shown as:

$$
\left(\begin{array}{cccc}
a_{11} & a_{12} & \cdots & a_{1 n} \\
a_{21} & a_{22} & \cdots & a_{2 n} \\
\vdots & \vdots & & \vdots \\
a_{n 1} & a_{n 2} & \cdots & a_{n n}
\end{array}\right)
$$

Accordingly, the fuzzy PCM is displayed as:

$$
\left(\begin{array}{cccc}
a_{11 \mid} a_{11 m} a_{11 u} & a_{12 l} a_{12 m} a_{12 u} & \cdots & a_{1 n l} a_{1 n m} a_{1 n u} \\
a_{21 \mid} a_{21 m} a_{21 u} & a_{22 l} a_{22 m} a_{22 u} & \cdots & a_{2 n l} a_{2 n m} a_{2 n u} \\
\vdots & \vdots & & \vdots \\
a_{m 1 \mid} a_{m 1 m} a_{m 1 u} & a_{m 2 l} a_{m 2 m} a_{m 2 u} & \cdots & a_{m n l} a_{m n m} a_{m n u}
\end{array}\right)
$$


2. Fuzzy Extent Analysis for Calculation of Performance Ratings, Weight Multiplication from Hierarchy, and Weight Summation.

The values of the fuzzy synthetic extent with respect to the $i^{\text {th }}$ criterion are defined as:

$$
\begin{gathered}
S_{t}=\sum_{j=1}^{m} M_{g t}^{j} \otimes\left[\sum_{t=1}^{n} \sum_{j=1}^{m} M_{g t}^{j}\right]^{-1} \\
\sum_{j=1}^{m} M_{g i}^{j}=\sum_{j=1}^{m} I_{i j}, \sum_{j=1}^{m} m_{i j}, \sum_{j=1}^{m} u_{i j} \\
\sum_{i=1}^{n} \sum_{j=1}^{m} M_{i j}, \frac{1}{\sum_{n}^{i=1} \sum_{m}^{j=1} u_{i j}}, \frac{1}{\sum_{n}^{i=1} \sum_{m}^{j=1} m_{i j}}, \frac{1}{\sum_{n}^{i=1} \sum_{m}^{j=1} l_{i j}}
\end{gathered}
$$

Where $\mathrm{I}$ is the lower limit value, $\mathrm{m}$ is the most promising value and $\mathrm{u}$ is the upper limit value.

The degree of possibility $M_{2}=\left(I_{2}, m_{2}, u_{2}\right) \geq M_{1}=\left(l_{1}, m_{1}, u_{1}\right)$ is defined as:

$$
\begin{aligned}
& V\left(M_{1} \geq M_{2}\right)=\text { hgt }\left(M_{2} \cap M_{1}\right)=\mu(d) \\
& =\frac{I_{1}-u_{1}}{\left(m_{2}-u_{2}\right)-\left(m_{1}-u_{1}\right)}, \text { otherwise }
\end{aligned}
$$

where $\mu(d)$ represents is the highest intersection between two fuzzy values. In order to between $\mathrm{M} 1$ and $\mathrm{M} 2$, calculating both $\mathrm{V}(\mathrm{M} 2 \geqslant \mathrm{M} 1)$ and $\mathrm{V}(\mathrm{M} 1 \geqslant \mathrm{M} 2)$ is necessary.

The degree of possibility for a convex fuzzy number to be higher than $k$ convex fuzzy numbers $M_{i}(i=1,2, \ldots, k)$ can be defined by:

$$
V\left(M_{1}, M_{2}, \ldots, M_{k}\right)=\min V\left(M \geq M_{i}\right), i=1,2, \ldots, k
$$

Assuming $d\left(A_{i}\right)=\min V\left(S_{i} \geq S_{k}\right)$.

For $k=1,2, \ldots, n ; k \neq i$, the weight vector is given by: 


$$
W=\left(d^{\prime}\left(A_{1}\right), d^{\prime}\left(A_{2}\right), \ldots d^{\prime}\left(A_{n}\right)\right)^{\top}
$$

Where $A_{i}(i=1,2,3,4,5, \ldots, n)$ are $n$ elements.

3. Normalizing weight vectors, through:

$$
W=\left(d\left(A_{1}\right), d\left(A_{2}\right), \ldots d\left(A_{n}\right)\right)^{\top}
$$

Where $\mathrm{W}$ is a non-fuzzy number.

Finally, adding the weights per option multiplied by the weights of the corresponding criteria gives the final score for each option.

\section{3) QUESTIONNAIRE DESIGN}

The survey questionnaire comprised of 14 pairwise comparison questions related to tourist-facing TSCM criteria. The notations of relative importance are on the basis of the 9-point pairwise comparison value in Table 1. Accordingly, the linguistic variables were presented to the respondents regarding the importance scales of a particular TSCM performance metrics comparison. In order to ensure instrument validity, we consulted the questionnaire with 5 experienced tourism practitioners to check for confusing and misleading questions. Subsequently, a pilot test was conducted to test the survey upon the intended population. The tourism-facing TSCM performance metrics used are adapted from the framework presented in Yilmaz and Bititci (2006), a suggested model for performance measurement system for tourism considered exhaustive to encapsulate the whole tourism experience which is largely non-existent in other literature. The framework is constructed into 4 stages making up a level-1, and 10 components construing level-2, as follows:

1. Win Order/Booking, which is the stage in which the customer has initial contact in the supply chain, spanning from information inquiry up to the purchasing completion. The breakdown of this phase is: purchasing cycle time, number of complaints during the booking process, and accuracy of information in the booking process.

2. Pre-Delivery/Pre-Travel, which is the stage in which the customer conducts necessary preparation upon travelling. The breakdown of this metric is: visa 
and/or other related documents handling cycle time, and accuracy of information about the destination.

3. Delivery/Travel, which is the stage in which the customer experiences the travelling itself. The delivery stage is comprised of: transportation services, accommodation services, and incoming travel agent/tour guide services.

4. Post Delivery/Post-Travel, which is the stage experienced by the customer after the travel. The metrics making up this stage is: customer satisfaction survey and qualitative feedback.

\section{RESULTS AND DISCUSSION}

In aim to examine the relative importance of the criteria and sub-criteria of tourism supply chain management (TSCM) performance, this study managed to collect 331 questionnaires that were returned completely filled and useable by the respondents, which accounts for $73 \%$ out of the total distributed forms. Brief demographic characteristics of the tourists are provided in Table 2. The information points to the dominance of female respondents, alluding to the reasoning that generally women are more likely to participate in surveys compared to men (James et al., 2017). Moreover, the likable compliance of the younger generation or millennials, which are generally those born between 1981 to 2000 (Floros et al., 2021) or at the age range of 19 to 39 in the time of study, towards online questionnaires eventuated the high figures of the category. The participation of international tourists is relatively low due to the COVID19 pandemic that significantly affected international tourist visits to Indonesia in year 2020. Nevertheless, the collected sample was considered sufficient to provide insights towards the study.

The responses from end-customers of the tourism supply chain provided the basis for pairwise relative weightings to reveal the importance of TSCM performance components. As laid out in the literature review section, the criteria of performance used in this study are considered to also reflect the SERVQUAL attributes as presented in Yilmaz \& Bititci (2006). For example, the performances in a particular stage of the supply chain should also entail that of the SERVQUAL dimensions, namely reliability, responsiveness, assurance, tangibles, and empathy. 


\begin{tabular}{|c|c|c|}
\hline Characteristics & Frequency & Percentage \\
\hline \multicolumn{3}{|l|}{ Age, years } \\
\hline Below 20 & 0 & $0 \%$ \\
\hline $20-24$ & 16 & $4.83 \%$ \\
\hline $25-29$ & 215 & $64.9 \%$ \\
\hline $30-34$ & 65 & $19.6 \%$ \\
\hline $35-39$ & 14 & $4.3 \%$ \\
\hline $40-44$ & 15 & $4.5 \%$ \\
\hline $45-49$ & 3 & $0.9 \%$ \\
\hline Above 50 & 3 & $0.9 \%$ \\
\hline \multicolumn{3}{|l|}{ Sex } \\
\hline Male & 110 & $33.4 \%$ \\
\hline Female & 219 & $66.6 \%$ \\
\hline $\mathrm{N} / \mathrm{A}$ & 2 & $0.6 \%$ \\
\hline \multicolumn{3}{|l|}{$\begin{array}{l}\text { Tourist } \\
\text { Category }\end{array}$} \\
\hline Domestic & 274 & $83 \%$ \\
\hline International & 57 & $17 \%$ \\
\hline
\end{tabular}

Table 2: Demographic Characteristics of 331 Respondents.

Results from the F-AHP analysis are presented in Figure 1 in terms of local weights and Table 3 in terms of overall weights and ranks. It shows that pre-travel stage was considered the most essential criteria in level-1, followed by win order/booking. This information suggests that tourists highly regard preparation prior to travelling as a critical component to ensure overall satisfaction in the travelling experience itself. The particular finding somewhat highlights that in Lin et al. (2009) who asserts that tourist complaints tend to arise in the arrangement and pre-information dimensions, thus alluding the need for tourism and travel suppliers to establish strong service-related constructs in the pre-travel stage of the tourism supply chain. On the other hand, posttravel is the least considered component in level-1, which may point to low engagement between tourists and tourism service providers once the travelling is over. In wake of this finding, companies along the chain should put more emphasis in encouraging tourists to be involved in recalling their travelling experiences when the travel is over, which could provide as important inputs for marketing purposes. Park \& Santos (2017) underline that travel providers can benefit from promotional narratives by building on the memories of previous tourists. In recent years, it is common for the 
younger generation of travellers i.e. millennials to share their travelling experiences on the internet after the trip which ignites travel inspiration for other potential tourists (Şchiopu et al., 2016; Llecthy, 2020). As millennials do search for authentic and memorable experiences, and oftentimes gravitate to immerse in the lifestyle of the local community (Veiga et al., 2017), considerable information related to the tourism value delivery are predisposed. Accordingly, the aforementioned lack of engagement gap should be bridged by the travel providers in order to maximize marketing benefits.

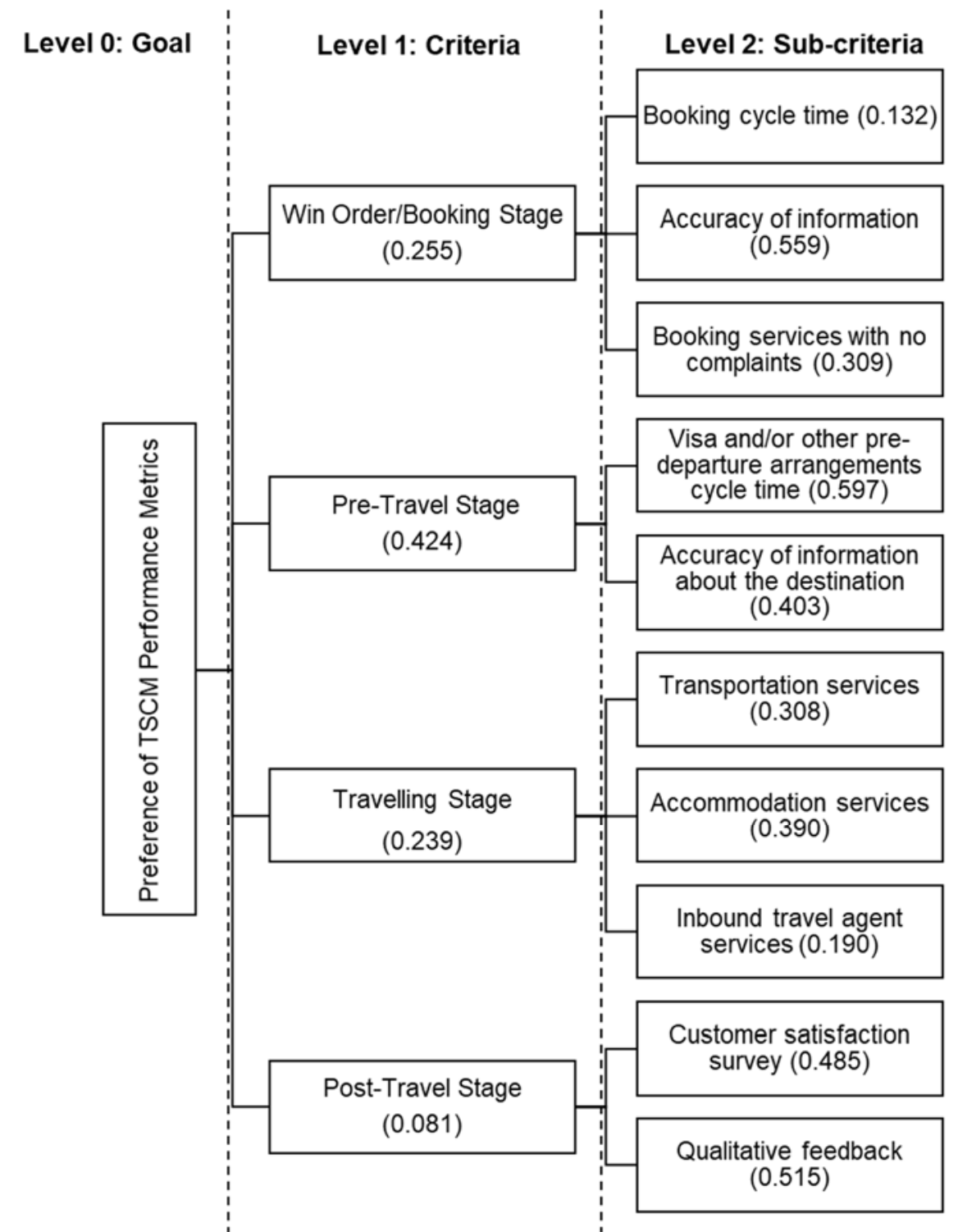

Figure 1: Decision Hierarchy of Customer-Facing TSCM Performance Criteria.

Our results 1 also signify sub-criteria importance for each stage in the tourism supply chain. In the win order/booking stage, accuracy of information is the most important aspect from the tourists' standpoint. Similarly, it is also presented as the 
most important requirement for information dissemination in the tourism industry (Pertheban et al., 2019). Moreover, studies such as Park \& Santos (2017), Choi et al. (2012), and Bieger \& Laeser (2004) underpin the critical aspect of information integration into the travelling planning process, since decision-making for travelling is considered a complex one (Moore et al., 2012). Therefore, tourism providers should ensure for providing updated and non-discrepant information, one which can be supported by sourcing in previous travellers' online testimonies as mentioned earlier. On the other hand, booking cycle time is found as the least important measure in the booking phase, which may imply that the information collection and its reassurance that would oftentimes require lengthy extents, accordingly overcomes the need for the swift booking process.

\begin{tabular}{|c|c|c|c|c|}
\hline $\begin{array}{l}\text { Level } 1 \\
\text { Criteria }\end{array}$ & Level 2 Sub-criteria & $\begin{array}{l}\text { Importance } \\
\text { of level } 1 \\
\text { (Rank) }\end{array}$ & $\begin{array}{l}\text { Local } \\
\text { Importance } \\
\text { of level } 2 \\
\text { (Rank) }\end{array}$ & $\begin{array}{l}\text { Global } \\
\text { Importance } \\
\text { of level } 2 \\
\text { (Rank) }\end{array}$ \\
\hline 1.Win Order & $\begin{array}{l}\text { Booking cycle time } \\
\text { Accuracy of information in the } \\
\text { booking process } \\
\text { Booking services with no complaints }\end{array}$ & $0.255(2)$ & $\begin{array}{l}0.132(3) \\
0.559(1) \\
0.309(2)\end{array}$ & $\begin{array}{l}0.033(10) \\
0.142(3) \\
0.078(5)\end{array}$ \\
\hline 2. Pre-Travel & $\begin{array}{l}\text { Visa and/or other pre-departure } \\
\text { arrangements cycle time } \\
\text { Accuracy of information about the } \\
\text { destination }\end{array}$ & $0.424(1)$ & $\begin{array}{l}0.597(1) \\
0.403(2)\end{array}$ & $\begin{array}{l}0.253(1) \\
0.171(2)\end{array}$ \\
\hline 3. Travelling & $\begin{array}{l}\text { Transportation services } \\
\text { Accommodation services } \\
\text { Inbound travel agent services }\end{array}$ & $0.239(3)$ & $\begin{array}{l}0.308(2) \\
0.390(1) \\
0.190(3)\end{array}$ & $\begin{array}{l}0.073(6) \\
0.093(4) \\
0.045(7)\end{array}$ \\
\hline 4. Post-Travel & $\begin{array}{l}\text { Customer satisfaction survey } \\
\text { Qualitative feedback }\end{array}$ & $0.081(4)$ & $\begin{array}{l}0.485(2) \\
0.515(1)\end{array}$ & $\begin{array}{l}0.039(9) \\
0.041(8)\end{array}$ \\
\hline
\end{tabular}

Table 3: Overall Weights of Customer-Facing TSCM Performance Criteria.

In the pre-travel stage, the highest weighting was found for visa and other predeparture arrangements cycle time. The metric in specific is considered a focal point as the travelling backdrop in Indonesia is significantly affected by the global COVID19 pandemic. This condition renders strict travelling regulations thus propelling additional documents as a "pass" to travel such as medical certificates declaring free of the COVID-19 virus. Furthermore, potential rise of a so-called "immunity certificate" is pointed out in Chen et al. (2020), which is anticipated to change the landscape of pre-travel arrangements in the near future. It is worth noting however, that accuracy of information about the destination is weighted comparatively close towards the arrangements cycle time, which indicate that tourists are continuously seeking for 
travelling information despite have been confirmed upon initial arrangements. Park \& Santos (2017) and Choi et al. (2012) also signify the importance of tourists' pre-travel information, the latter recognizing that tourists were still in search of information even after the purchase of vacation products. This could support the argument that tourists are contingent towards "unplanned" visits at a certain destination because of constant information search about the destination after booking the travel (Hwang \& Fesenmaier, 2011).

In regards to the travelling stage, services related to accommodation is the most critical component. Likewise, relative emphasis on accommodation from the perspective of travel businesses is also shown in Lin et al. (2009). The previous study also highlights low prioritization towards local guides services, confirming our finding related to the low weighting for inbound travel agencies/local guides. Information and communication technology (ICT) through app-based smart phones has substantially altered tourists' behaviour (Liang et al., 2017). Travellers are therefore able to perform at-the-destination-related tasks such as locating people, objects, and places, creating routes, and obtaining information about travelling conditions (Lai, 2015). Such circumstance may suggest the modest need for inbound travel agents or guides.

In the post-travel stage, qualitative feedback is seen as the most important component, denoting that tourists' value more than mere traditional customer survey questionnaires. The usefulness of qualitative travel feedback is appraised in Roddis et al. (2019), which is regarded to provide richer insights of the tourists' experience. Nevertheless, Pencarelli et al. (2020) notes that millennial travellers are apt to share their travelling experiences in the post-travel stage predominantly through social media outlets in Facebook and Instagram as opposed to taking part in that of web pages of hotels, travel agencies, and tour operators. However, they also note that tourists are more inclined to share commentary on the online booking platforms, suggesting a subtle disengagement from certain providers in the tourism supply chain. Appropriately, these companies may promote more innovative ways for engaging millennial tourists to experience sharing. For instance, by creating online discussion forums or platforms that allows the traveller to share his/her experiences with their close friends. After all, exposure to peers is a critical driving factor for the millennials to share their travelling experiences in the post travel phase (Liu et al., 2018). 
Global weights of level-2 sub-criteria are shown in the last column of Table 2. Considering current and future paramount circumstances surrounding travelling arrangements as a consequence of the COVID-19 pandemic, it is not surprising that the two metrics in the pre-travel stage (visa and other pre-departure arrangements cycle time and accuracy of information about the destination) dominates the ranks. Moreover, it is worth highlighting that accuracy of information in both pre-travel and booking arrangements are of high order. The reason towards such emphasis may relate to the fact that todays' millennial tourists have abundant access of information obtained from the online platform (Ketter, 2021), rendering "the perfect information" as a necessity. Furthermore, Wong et al. (2019) and Xiang \& Law (2013) acknowledge that extensive information searches prior to travel are conducted by virtue to reduce perceived risk. In accordance to this, in wake of the COVID-19 pandemic that significantly altered how the tourism industry operates, valuation of information is ever so amplified. In specific, tourists are subject to the need for more information reflecting assurance for a safer travel. Nazneen et al. (2021) underline that COVID-19 has greatly affected tourists travel decision and their perceptions of hygiene and safety. Concurrently, Wen et al. (2021) recognizes that potential tourists may express a newfound interest in destinations' hygiene and cleanliness, medical facilities, and population density when making travel-related decisions.

In light of what has been discussed above, the main implications for tourism supply chain providers would revolve around efforts for establishing profound proximities with the tourists, particularly in the pre-travel and post-travel phases. This in turn would provide richer insights towards identifying and managing specific newfound tourist characteristics and other related information that serves for maximizing value delivery, especially in regards to the COVID-19 pandemic that entails heavy consideration towards safety and security measures. For example, providers in the pre-travel stage may foresee to implement mandatory travel insurances covering illness cases, including COVID-19. Just recently, Indonesia's Ministry of Tourism and Creative Economy have promoted the CHSE-based (Cleanliness, Health, Safety, and Environmental Sustainability) protocols as an adaptive measure towards the "new normal era" post COVID-19 outbreak (Handayani et al., 2021). Accordingly, chain providers in the travelling stage such as transportation companies and at the- 
destination suppliers, especially accommodation, one with which the tourist considerably spends the majority of his/her time, should adjust towards providing services through the CHSE-based guidelines. Providers should also publicize the quality of hygiene and health facilities at the destination, which would be necessary to shape the newly desired destination image.

\section{CONCLUSIONS}

This research was motivated by the very limited empirical studies into an allinclusive TSCM performance framework focusing on the end-customer i.e., tourist attitude. Previous studies drawing the gap for this study include Lin et al. (2009), Huang (2018), and Palang \& Tippayawong (2019), which centre performances on the companies' frame of reference. Meanwhile, other works evaluating tourists' standpoint in TSCM such as Xu \& Gursoy (2015) and Ghaderi et al. (2018) refrain the full-scale view of the supply chain. Accordingly, the objective of this study was to examine the exhaustive tourist-facing TSCM performance by employing the F-AHP approach to reveal relative importance of the performance attributes, one that is original in the TSCM literature considering the state of tourism in the COVID-19 era. The agenda is considered imperative as tourists are directly involved in all stages of the tourism supply chain, and to the fact the tourism product is merely that of customer satisfaction and experience. Our research was conducted within the context of tourism in Indonesia upon a sample of 331 tourists, which mainly received responses from the millennial demographic category.

Our findings provided highlights concerning essential tourism supply chain stages and performance criteria that requires more focus. Respectively, tourism providers such tour operators, travel agencies, and transportation and accommodation companies may seek towards enhancing specific constructs and strategically reframe their resources related to the tourism product delivery, as tourists do consider certain attributes more important than others. Results in the criteria level point that the stages prior to travel were the quintessential components, with the pre-travel phase pointed as the most critical one. This implies that proper preparation in the pre-travel stage is imperative towards tourists' satisfaction in the travelling experience itself. The actual travel phase itself comes as third in tourists' consideration, with an emphasis pointed 
towards accommodation services. Results also point post-travel stage to be the least considered phase, implying that service providers should encourage tourists into more engagement when the travel is over which is essential towards future reconciliation and future marketing initiatives for the tourism product delivery. Considering the overall sub-criteria ranks, visa and/or other pre-travel documents arrangement cycle time is the first in priority. This comes as no surprise when taking into account the paramount regulations required for travelling both domestically and internationally, courtesy of the COVID-19 pandemic. Moreover, information accuracy in the pre-travel and win order/booking stage is ranked $2^{\text {nd }}$ and $3^{\text {rd }}$, respectively, alluding to the necessity of perfect information to ensure tourist satisfaction especially regarding health and safety measures.

This research is not without its limitations. The decline of the tourism industry in Indonesia due to the COVID-19 pandemic resulted in limited number of respondents, particularly from the international tourist category. Moreover, the high proportion of respondents from the millennial category could lead to distortion of information. Future studies may include a more proportionate demography of tourists, increase the number of respondents, and broaden the geographical research area to ensure the validity of what is being presented here. Furthermore, researchers may explore TSCM performance from specific tourism supply chains such as that of sports, medical, or marine tourism, which may present valuable insights towards literature and practice.

\section{References}

Bai, J.; Chen, Y. An analysis of the triadic relationship between airline, destination, and travel agency: applying nucleolus theory to assess power loss and the profit allocation approach. Soft Computing, Vol. 25, No. 8, 2021, pp. 5881-5893.

Bieger, T.; Laesser, C. Information sources for travel decisions: Toward a source process model. Journal of Travel Research, Vol. 42, No. 4, 2004, pp. 357-371.

BPS Nusa Tenggara Timur. Nusa Tenggara Timur Province in Figures. Jakarta: CV. Nario Sari, 2019. 
Chan, F.T.; Kumar, N. Global supplier development considering risk factors using fuzzy extended AHP-based approach. Omega, Vol. 35, No. 4, 2007, pp. 417-431.

Chang, D.Y. Applications of the extent analysis method on fuzzy AHP. European Journal of Operational Research, Vol. 95, No. 3, 1996, pp. 649-655.

Chen, L.H., Freedman, D.O.; Visser, L.G. COVID-19 Immunity Passport to Ease Travel Restrictions? Journal of Travel Medicine, Vol. 27, No. 5, 2020, pp. 1-3.

Cho, D.W.; Lee, Y.H.; Ahn, S.H.; Hwang, M.K. A framework for measuring the performance of service supply chain management. Computers and Industrial Engineering, Vol. 62, No. 3, 2012, pp. 801-818.

Choi, S.; Lehto, X.Y., Morrison, A.M.; Jang, S.C. Structure of travel planning processes and information use patterns. Journal of Travel Research, Vol. 51, No. 1, 2012, pp. 26-40.

Cucculelli, M.; Gof, G. Does sustainability enhance tourism destination competitiveness? Evidence from Italian Destinations of Excellence. Journal of Cleaner Production, Vol. 111, 2016, pp. 370-382.

Evans, N.; Stonehouse, G.; Campbell, D. Strategic Management for Travel and Tourism. London: Routledge, 2002.

Floros, C.; Cai, W.; McKenna, B.; Ajeeb, D. Imagine being off-the-grid: millennials' perceptions of digital-free travel. Journal of Sustainable Tourism, Vol. 29, No. 5, 2021 , pp. 751-766.

Fu, H.; Chu, K.; Chao, P.; Lee, H. (2011). Using fuzzy AHP and VIKOR for benchmarking analysis in the hotel industry. The Service Industries Journal, Vol. 31, No. 14, 2011, pp. 2373-2389.

Ghaderi, Z.; Hatamifar, P.; Khalilzadeh, J. (2018). Analysis of tourist satisfaction in 551 
tourism supply chain management. Anatolia, Vol. 29, No. 3, 2018, pp. 433-444.

González-Torres, T.; Rodríguez-Sánchez, J.L.; Pelechano-Barahona, E. Managing relationships in the Tourism Supply Chain to overcome epidemic outbreaks: The case of COVID-19 and the hospitality industry in Spain. International Journal of Hospitality Management, Vol. 92, 2021, pp. 102733.

Guo, X.; Ling, L.; Dong, Y.; Liang, L. Cooperation contract in tourism supply chains: The optimal pricing strategy of hotels for cooperative third party strategic websites. Annals of Tourism Research, Vol. 41, 2013, pp. 20-41.

Handayani, F.; Sylvina, V.; Lestari, A. Toward New Normal: Bali Tourism Goes Extra Mile. In IOP Conference Series: Earth and Environmental Science. IOP Publishing, Vol. 704, No. 1, 2021, pp. 012025.

Heikkilä, J. (2002). From supply to demand chain management: Efficiency and customer satisfaction. Journal of Operations Management, Vol. 20, No. 6, 2002, pp. 747-767.

Huang, C.-W. Assessing the performance of tourism supply chains by using the hybrid network data envelopment analysis model. Tourism Management, Vol. 65, 2018, pp. 303-316.

Hwang, Y.H.; Fesenmaier, D.R. Unplanned tourist attraction visits by travellers. Tourism Geographies, Vol. 13, No. 3, 2011, pp. 398-416.

Ip, C.; Law, R.; Lee, H.A. The evaluation of hotel website functionality by fuzzy analytic hierarchy process. Journal of Travel \& Tourism Marketing, Vol. 29, No. 3, 2012, pp. 263-278.

James, A.; Ravichandran, S.; Chuang, N.K.; Bolden, E. Using Lifestyle Analysis to Develop Lodging Packages for Staycation Travelers: An Exploratory Study. Journal of Quality Assurance in Hospitality and Tourism, Vol. 18, No. 4, 2017, pp. 387-415. 
Jiang, Y.; Ritchie, B.W. Disaster collaboration in tourism: Motives, impediments and success factors. Journal of Hospitality and Tourism Management, Vol. 31, 2017, pp. 70-82.

Kannan, D.; Khodaverdi, R.; Olfat, L.; Jafarian, A.; Diabat, A. Integrated fuzzy multi criteria decision making method and multiobjective programming approach for supplier selection and order allocation in a green supply chain. Journal of Cleaner Production, Vol. 47, 2013, pp. 355-367.

Kementrian Pariwisata Indonesia. Laporan Akuntabilitas Kinerja Kementrian Pariwisata. Kementrian Pariwisata Indonesia, 2018 [Tourism Ministry of Indonesia. Performance Accountability Report of the Tourism Ministry of Indonesia. Tourism Ministry of Indonesia, 2018].

Ketter, E. Millennial travel: tourism micro-trends of European Generation Y. Journal of Tourism Futures, Vol. 7, No. 2, 2021, pp. 192-196.

Kubler, S.; Robert, J.; Derigent, W.; Voisin, A.; Le Traon, Y. A State-of the-Art Survey \& Testbed of Fuzzy AHP (FAHP) Applications. Expert Systems with Applications, Vol. 65, 2016, pp. 398-422.

Lai, I.K.W. Traveler Acceptance of an App-Based Mobile Tour Guide. Journal of Hospitality and Tourism Research, Vol. 39, No. 3, 2015, pp. 401-432.

Liang, S.; Schuckert, M.; Law, R.; Masiero, L. The relevance of mobile tourism and information technology: an analysis of recent trends and future research directions. Journal of Travel and Tourism Marketing, Vol. 34, No. 6, 2017, pp. 732-748.

Lin, C.T.; Lee, C.; Chen, W.Y. Using fuzzy analytic hierarchy process to evaluate service performance of a travel intermediary. Service Industries Journal, Vol. 29, No. 3, 2009, pp. 281-296. 
Liu, H.; Wu, L.; Li, X. Social media envy: How experience sharing on social networking sites drives millennials' aspirational tourism consumption. Journal of Travel Research, Vol. 58, No. 3, 2019, pp. 355-369.

Lonely Planet. Best in Travel 2020. Dublin: Lonely Planet, 2019.

Makui, A.; Nikkhah, Z. Designing fuzzy expert system for creating and ranking of tourism scenarios using fuzzy AHP method. Management Science Letters, Vol. 1, No. 1, 2011, pp. 29-40.

Mehrjerdi, Y.Z. Developing Fuzzy TOPSIS Method based on Interval valued Fuzzy Sets. International Journal of Computer Applications, Vol. 42, No. 14, 2012, pp. 7-18.

Mete, B.; Acuner, E. A Value Chain Analysis of Turkish Tourism Sector. International Journal of Business and Management Studies, Vol. 3, No. 2, 2014, pp. 499-506.

Moore, K.; Smallman, C.; Wilson, J.; Simmons, D. Dynamic in-destination decisionmaking: An adjustment model. Tourism Management, Vol. 33, No. 3, 2012, pp. 635645.

Nazneen, S.; Hong, X.; Ud Din, N. COVID-19 crises and tourist travel risk perceptions. SSRN Electronic Journal, May 2020, pp. 1-8.

Nilashi, M.; Yadegaridehkordi, E.; Ibrahim, O. Analysis of Travellers ' Online Reviews in Social Networking Sites Using Fuzzy Logic Approach. International Journal of Fuzzy Systems, Vol. 21, No. 5, 2019, pp. 1367-1378.

Palang, D.; Tippayawong, K.Y. Performance evaluation of tourism supply chain management: the case of Thailand. Business Process Management Journal, Vol. 25, No. 6, 2019, pp. 1193-1207.

Parasuraman, A. Customer service in business-to-business markets: an agenda for research. Journal of Business \& Industrial Marketing, Vol. 13, No 4/5, 1998, pp. 309554 
321.

Park, S.; Santos, C.A. Exploring the Tourist Experience: A Sequential Approach. Journal of Travel Research, Vol. 56, No. 1, 2017, pp. 16-27.

Pencarelli, T.; Gabbianelli, L.; Savelli, E. The tourist experience in the digital era: The case of Italian millennials. Sinergie Italian Journal of Management, Vol. 38, No. 3, 2020, pp. 165-190.

Roddis, S.; Winter, S.; Zhao, F.; Kutadinata, R. Respondent preferences in travel survey design: An initial comparison of narrative, structured and technology-based travel survey instruments. Travel Behaviour and Society, Vol. 16, 2019, pp. 1-12.

Şchiopu, A.F.; Pădurean, A.M.; Tală, M.L.; Nica, A.M. (2016). The influence of new technologies on tourism consumption behavior of the millennials. Amfiteatru Economic Journal, Vol. 18, No. 10, 2016, pp. 829-846.

Sigala, M. A supply chain management approach for investigating the role of tour operators on sustainable tourism: the case of TUI. Journal of Cleaner Production, Vol. 16, No. 15, 2008, pp. 1589-1599.

Song, H. Tourism Supply Chain Management. London: Routledge, 2010.

Soratana, K.; Landis, A.E.; Jing, F.; Suto, H.. Supply Chain Management of Tourism Towards Sustainability. Heidelberg: Springer, 2021.

Sutono, A. Supply chain management: Implementation issues and research opportunities in tourism industry. Uncertain Supply Chain Management, Vol. 7, No. 3, 2019, pp. 427-438.

Szpilko, D. Tourism Supply Chain-Overview of Selected Literature. Procedia Engineering, Vol. 182, 2017, pp. 687-693. 
Tseng, P.H.; Yip, T.L. An evaluation model of cruise ports using fuzzy analytic hierarchy process. Maritime Business Review, Vol. 6 No. 1, 2021, pp. 22-48.

Veiga, C.; Santos, M.C.; Águas, P.; Santos, J.A.C. Are millennials transforming global tourism? Challenges for destinations and companies. Worldwide Hospitality and Tourism Themes, Vol. 9, No. 6, 2017, pp. 603-616.

Vollmann, T.E.; Cordon, C. Building Successful Customer - Supplier Alliances. Long Range Planning, Vol. 31, No. 5, 1998, pp. 684-694.

Wang, C.N.; Nguyen, N.A.T.; Dang, T.T.; Lu, C.M. A compromised decision-making approach to third-party logistics selection in sustainable supply chain using fuzzy AHP and fuzzy VIKOR methods. Mathematics, Vol. 9, No. 8, 2021, pp. 886.

Wang, Y.; Jung, K.; Yeo, G.; Chou, C. Selecting a Cruise Port of Call Location using the Fuzzy-AHP Method: A case Study in East Asia. Tourism Management, Vol. 42, 2014, pp. 262-270.

Wen, J.; Kozak, M.; Yang, S.; Liu, F. COVID-19: Potential effects on Chinese citizens' lifestyle and travel. Tourism Review, Vol. 76, No. 1, 2021, pp. 74-87.

Wong, J.W.C.; Lai, I.K.W.; Tao, Z. Sharing memorable tourism experiences on mobile social media and how it influences further travel decisions. Current Issues in Tourism, Vol. 23, No. 4, 2020, pp. 1773-1787.

World Tourism Organization. International Tourism Highlights. Madrid: UNWTO, 2020.

Xiang, Z.; Law, R. Online competitive information space for hotels: An information search perspective. Journal of Hospitality Marketing \& Management, Vol. 22, No. 5, 2014, pp. 530-546.

Xu, X.; Gursoy, D. Influence of sustainable hospitality supply chain management on 556 
customers' attitudes and behaviors. International Journal of Hospitality Management. Vol 49, 2015, pp. 105-116.

Yilmaz, Y.; Bititci, U. Performance measurement in the value chain: Manufacturing v. tourism. International Journal of Productivity and Performance Management, Vol. 55 No. 5, 2006, pp. 371-389.

Zadeh, L.A.. Fuzzy sets. Information and Control, Vol. 8, No. 3, 1965, pp. 338-353.

Zhang, X.; Song, H.; Huang, G.Q. Tourism supply chain management: A new research agenda. Tourism Management, Vol. 30, No. 3, 2009, pp. 345-358.

Zhao, X.; Hou, J. Applying the Theory of Constraints Principles to Tourism Supply Chain Management, Journal of Hospitality \& Tourism Research, 2021, https://doi.org/10.1177/1096348021996791

Article info: Received 12/04/2021. Accepted 22/10/2021. Refereed anonymously. 